Fragility within Stability: The State, the Clan and Political Resilience in Somaliland

Rebecca Richards

Keele University

r.richards@keele.ac.uk

DOI: $10.1080 / 01436597.2020 .1730693$ 


\begin{abstract}
:
Even in the context of a relatively flourishing state, fragility can be an enduring feature of a political system, particularly in the case of recently established or unrecognised states. This article examines the nature of statebuilding in a specific context to question the assumption that forms of hybrid governance or pre-existing forms of governance are a necessary evil be tolerated but which needs ultimately to be overcome during statebuilding. It does this by adopting the language of resilience and focusing on the case of Somaliland to highlight the role of clan governance as a mechanism of political resilience and as a means of promoting the flexibility required for statebuilding. Yet, at the same time, the process of statebuilding often involves formalising governance and limiting the role of traditional social-political forms of governance such as clans, ignoring their role in legitimating and stabilizing the political system. However, as this article argues, stability and fragility are inextricably linked; while the clan system has been an important force in stabilizing the state, it has also become a pressure point for the state's latent fragility. By contextualising fragility and stability within the language of resilience, though, this symbiotic relationship can be better analysed.
\end{abstract}

Keywords: statebuilding, resilience, fragile states, hybrid governance, Somaliland 


\section{Fragility within Stability: The State, the Clan and Political Resilience in Somaliland}

Since its 1991 declaration of independence, Somaliland has functioned as an unrecognised state, balancing demands of international expectations of statehood with domestic necessities for provision and stability. A multitude of factors, influences, actors and even motivations have contributed to enabling and fostering stability throughout the turbulent processes of post-conflict reconciliation and statebuilding. Somaliland's stability has been accomplished within a relatively short period of time and, importantly, with very little involvement of or interference by actors external to the Somaliland community. However, as a political entity not protected or legitimised by sovereign recognition and thus without the benefits that affords, Somaliland is under constant threat of precarity, if not in a constant state of fragility. Although a relatively flourishing entity, Somaliland is threatened by factors that stem from its self-led statebuilding process. Indeed, whilst also facing threats from environmental factors and regional occurrences, the biggest continuing threat to Somaliland is breakdown in the political process and in the relationship between social and political institutions. Because of the web of social, economic and political forces and motivations maintaining the stability necessary for vital political growth and economic development, an inherent fragility exists. However, there are points of continuity and resilience within the Somaliland project which act to balance the inextricable link between fragility and stability.

Drawing on observational research, government and civil society interviews in Somaliland, and ideational work drawn from intellectual themes apparent from those, this article examines statebuilding in Somaliland through the lens of resilience in analysing the role of traditional governance institutions as a mechanism of resilience. Statebuilding here is defined as 'the creation or recovery of the authoritative, legitimate, and capable governance institutions that can provide for security and the necessary rule-of-law conditions for economic and social development'. ${ }^{1}$ Successful statebuilding demands often drastic sociopolitical change, and within this, but often lacking explicit recognition within practice, is the need for legitimacy and societal acceptance of new governance mechanisms and relationships. More critically, statebuilding is a political-legal process concerned with formalism over informalism that in practice, as Richmond notes, 'is shorn of its historical and

\footnotetext{
${ }^{1}$ Sisk, Statebuilding, 1.
} 
social context, re-established as a procedural infrastructure, representing best practice and good governance, via an ideological preference for a certain form of state'. ${ }^{2}$ This is not to be confused with state formation, which historically is a more organic, and lengthy, process centred on the establishment of a social contract. Indeed, in modern statebuilding, the social contract is assumed as an end result, rather than the starting point of the process of creating the state.

When analysing statebuilding processes, the lens of resilience, specifically political resilience, opens scope for questioning statebuilding differently. Rather than focusing on success at achieving a pre-determined end, it better allows for questioning what makes governance and the state work and survive, and enhances understanding of how statebuilding takes place rather than assessing against assumptions about how it should take place. It forces inclusion of examining the interplay between actors, processes and mechanisms in achieving stability. This article begins to conceptualise political resilience, framing it within the context of socio-political relationships that characterise the state and underpin statebuilding.

Somaliland's government and governance are characterised by hybridity, with democratic structures and practices emerging from and alongside clan governance practices and institutions. Often seen as illiberal or deviant, hybrid governance continues to be perceived of a necessary evil rather than an acceptable condition; it is a means to an acceptably liberal end where a conditional acceptance of value continues to problematize domestic, particularly traditional or customary, mechanisms of governance as points of insecurity that must be eventually fixed. ${ }^{3}$ The argument here rejects this premise in highlighting the role of clan governance in enabling the flexibility required to facilitate and maintain the ongoing statebuilding process in Somaliland. However, although a factor that also allows for considerable flexibility, in Somaliland the 'traditional' is also a point of fragility. As a result, a complex web of intertwined forces create stability but at the same time also threaten it. Thus, as this article concludes, clan governance, as a mechanism of resilience, is also a pressure point for the state's latent fragility.

\footnotetext{
${ }^{2}$ Richmond, 'Failed'.

${ }^{3}$ See Boege, et al, "Hybrid”; MacGinty, "Indigenous"; Richmond, Peace.
} 


\section{POLITICAL RESILIENCE}

Political development and governance are typically discussed in terms of strength and stability. Almost always addressed in linear terms, states are placed along a spectrum between fragility and stability, with a calculation of a number of set indicators used to assess level of strength. Some measures quantify these criteria, providing numerical scores for the supposed stability (or fragility) of individual states. Whilst these mechanisms can be useful for providing a broad picture and identifying potential conflict, they are problematic when looking beyond the expected liberal democratic style of state and, ultimately, of governance. ${ }^{4}$ Further, the terms 'strength' and 'stability' denote rigidity, a connotation that carries weight in both perception and practice. The rigid frameworks that are established and the set expectations and measured criteria of assessment guide practice, including statebuilding. Because stability and fragility are opposite ends of the spectrum, it is difficult to then open understanding and practice to the potential co-existence of the two. Here, rigidity is a problem.

However, the conceptual lexicon of the social sciences disciplines has a term that may be more appropriate to use: resilience. Resilience is a contested yet malleable term that has cross-disciplinary applications. At its most basic definition, resilience means to 'bounce back,' and is 'often applied in relation to an entity or system's ability to return to normal functioning quickly following a disturbance'. ${ }^{5}$ There is a presumption of an underlying equilibrium, meaning the identification of a base is required in order to assess, or even discuss, resilience. Further understandings of resilience push the concept into the realm of adapting or learning in order to persist or survive. ${ }^{6}$ Here, building resilience is proactive, focusing on mitigating risk by strengthening capacity to protect against the "possible consequences of disruptions to society' that may occur due to a potentially disruptive occurrence or action. ${ }^{7}$ To some extent, this removes the assumption of normality or equilibrium, and instead places resilience within the context of change or adaptation.

Still, though, it is easy to place ideologically loaded assumptions into the understanding of 'beneficial' change, or to direct what type of adaptation is necessary. The literature on

\footnotetext{
${ }^{4}$ For discussion on security and peace, see Richmond, "Decolonising".

${ }^{5}$ Klein, et al, "Resilience"; Prior and Hagmann, "Measuring," 282.

${ }^{6}$ Prior and Hagmann, "Measuring," 282.

${ }^{7}$ Ibid.
} 
resilience is dominated by discussions of resilience within physical or social systems or infrastructure - health systems, education, roads, communications and environment are common topics. Within these, it is common to find critiques of ideological assumptions embedded within expectations and practice. ${ }^{8}$ Resilience is seen as designed and constructed rather than natural, carrying with it assumptions that the design is external, to be adopted and enacted by internal actors. In this regard resilience is a form of intervention that emphasises the need to create in order to foster change, with 'existing resilience factors' ${ }^{9}$ empowered, but with limited agency because of the constraints of intervention. As Chandler notes, resilience is a 'heuristic device, drawing attention to a particular governing rationality informing statebuilding policy prescriptions which work on the relational shaping of societal understandings and responses'. ${ }^{10}$ It is an 'ideological understanding of the limits of' liberal interventionism and the failures of domestic societies that 'produce the barriers to sustainable peace and development ${ }^{\prime 1}$. Viewing these barriers as reproductive and therefore perpetually self-harming, building resilience thus focuses on changing practice from within in order to 'teach' domestic actors ${ }^{12}$ the behaviours that will allow them to 'break out of the reproduction of the problems or "traps" that hinder liberal development and thus peace. ${ }^{13}$ In this way, building resilience is conceptualised as another mechanism of liberal governance through which life in the Global South is controlled or biopolitically governed. ${ }^{14}$

As a tool of stability and development policies and a topic of academic study, the discourse surrounding resilience highlights and maintains an external view of domestic power. This continues to problematize individualities by identifying and highlighting deviance from the liberal norm and expectations; deviance which is deemed a 'risk' or a 'threat,' despite its potential centrality and importance in domestic socio-political relationships. Critical understandings of resilience therefore must move beyond critiquing the liberal and must focus attention on what socio-political interrelations offer. In other words, reclaiming the concept of resilience by looking within rather than seeking to create a pre-determined end offers a useful analytical tool for understanding the complexity of socio-political structures

\footnotetext{
${ }^{8}$ See Chandler, "International"; Joseph, "Resilience".

${ }^{9}$ Manyena and Gordon, Bridging, 38.

${ }^{10}$ Chandler, "International," 278.

${ }^{11}$ Chandler, "International," 277.

${ }^{12}$ Finnemore, National.

${ }^{13}$ Chandler, "International," 277; Joseph, "Resilience"; Zebrowski, "Nature".

${ }^{14}$ See Duffield, "Challenging."
} 
and relationships within states; understanding that is necessary for the desired sustainability and stability of the built state. 'Building resilience,' therefore, must not only identify preexisting factors, but must recognise their value for their agency and their capacity within socio-political power. Resilience of socio-political structures and relationships - political resilience - must be a central consideration in statebuilding.

Resilience in the context of statebuilding is currently limited to considerations such as capacity building or systems like healthcare, infrastructure or education. Likely because of the dominance of the language of stability and fragility, resilience is not discussed in the context of political systems or governance. Removed from the confines of liberal interventionism, an understanding of resilience as adaptation or learning, as well as of 'springing back' is useful in the context of statebuilding in that it allows for a recognition of necessary flexibility within a disruptive process. ${ }^{15}$ Flipping our thinking on resilience from external liberal guidelines to internal functioning allows us to remove expectations of external design and create a more inclusive approach to understanding and analysing. This shift allows for a recognition of firstly, non-western, or even non-democratic, mechanisms of governance; and secondly, variations in how governance is formed, structured or enacted: an

understanding focused on what the domestic offers rather than what the domestic lacks. ${ }^{16}$ The use of resilience allows us to see beyond the linear and to recognise flux, change, learning, and adaptation that is part of the process of building, and strengthening, a lasting system of governance and government. To get to the point of lasting, though, often involves, or should involve, trial and error which itself means continuous change. A resilient state is one that can change, learn and adapt in order to be able to 'bounce back' to a point of relative peace and stability that is required for the process to continue: it is flexible, not rigid. It is here that the point of equilibrium becomes relevant as a point of continuity and thus stabilisation. ${ }^{17}$ Political resilience is not the opposite of fragility, but it is what helps hold fragility at bay.

\section{THE CLAN IN SOMALILAND}

The nearly decade long Somalia civil war was fought by numerous liberation movements against forces loyal to dictator Siad Barre. In February 1991, Barre's forces in Somaliland

\footnotetext{
15 Richards and Smith, "Playing"

16 See MacGinty, "Indigenous"; Richmond, Peace.

${ }^{17}$ See Boege, et al, "Hybrid"; Lemay-Hebert, "Statebuilding"; Roberts, "Hybrid."
} 
were defeated by the Somali National Movement (SNM), a liberation group rooted in the dominant Isaaq clan that advocated for a federal democratic government for Somalia. Throughout its existence, the leadership of the SNM recognised the importance of the pervasive Somali clan as a mechanism of governance and utilised them, specifically the elders, as a political and strategic tool to garner support during the war. This utilisation and integration of the clan proved indispensable for the SNM during the war and for the political leaders who embarked on the process of creating a Somaliland state following its May 1991 declaration of independence from Somalia.

The complex Somali clan system provides identification, protection and governance in Somaliland society. Kinship is a 'critical source of an individual's identity' ${ }^{18}$ and clan allegiance and dependence is regarded by many as part of being Somali. There are six main structuring clan-families that are then further divided into numerous clans, sub-clans, sub-sub clans, primary lineage groups, and diya-paying groups. ${ }^{19}$ Although clan distribution has altered drastically in the last century, in Somaliland the majority of the population come from one of three main clan-families: Isaaq, Dir, and Darood. The Isaaq is the most populous group in Somaliland, with some estimates placing it as high as eighty percent of the total population. ${ }^{20}$ The Somali clans and sub-clans serve an important function in Somali society, particularly in the nomadic communities. Established as a means of governance in the primarily nomadic and non-centralised pre-colonial Somali society, the clan continues to influence a person's place within society and the economy, as well as in determining relations between members of competing or allied clan-families. As clan-families are too big to act as collective political units, division into smaller clan and sub-clan groupings allows for better geographic, political, economic and social distinction and therefore more comprehensive control and protection. ${ }^{21}$ In this, the clan 'represents the social divisions of people into corporate political groups...By virtue of genealogy of birth, each individual has an exact place in society'. ${ }^{22}$ The clan further provides what Drysdale labels the Somali 'insurance policy' as clans take collective responsibility for their members, their losses and their security. ${ }^{23}$ Some have argued that increased attachment to other social groups or to territory as well as the

\footnotetext{
${ }^{18}$ Bradbury, Becoming, 18.

${ }^{19}$ Lewis, Modern.

${ }^{20}$ Bradbury, Becoming, 52.

${ }^{21}$ Lewis, Pastoral.

22 Ibid, 1-2.

${ }^{23}$ Drysdale, Stoics.
} 
emergence of a state, urbanisation, migration and the impacts of colonial or government policies, have altered and lessened the impact of the clan system. Whereas this can certainly be seen, especially in the South, in Somaliland colonial practices and post-independence isolation led to less disruption to the clan system and to more societal dependence upon clan provision and protection. Increasing pressure to lessen the impact of the clan, especially in political space, is found primarily in urban areas and amongst the younger generations, but, as Bradbury notes, 'the clan system remains an important feature of Somali social, political and economic life' in Somaliland. ${ }^{24}$ In Somaliland's hybrid system, the clan sits not only within the government, but also external to it as a pervasive mechanism of governance that serves to "hold[ing] the "traditions" of the clan at all levels. ${ }^{25}$

In Somaliland there has been continuity in the clan governance system that does not exist in other Somali inhabited territories. ${ }^{26}$ Throughout the Somalia civil war the clan was utilised by the SNM to foster support for the movement, creating what would be the permanent institutionalisation of the clan governance. Although rooted in political idealism and what could be described as a form of nationalism, the SNM's recognition of the importance and centrality of the clan to governance and government paved the way for its inclusion in the central governing structures of the emerging Somaliland state. Following the declaration of independence and throughout the initial period of statebuilding, the clan was central to the process, ${ }^{27}$ and symbolically the authority of the Somaliland government came from the clans as the elders absorbed authority from the SNM and then bestowed it upon the Somaliland government.

\section{STABILITY AND FRAGILITY OF SOMALILAND}

The road to peace in Somaliland was not bloodless, and the end of the war brought retributive acts against those who had supported Barre or were in opposition to the SNM. However, violence was kept to a minimum, largely because of the SNM's immediate reconciliation actions, particularly in allowing for a process led by clan elders rather than asserting its authority through force. The SNM's grassroots peacebuilding actions and its policy of peaceful co-existence amongst the clans facilitated an environment that was relatively

\footnotetext{
${ }^{24}$ Bradbury, Becoming, 18.

${ }^{25}$ Bradbury, "Peace-Enforcement," 81-82.

${ }^{26}$ Lewis, Modern.

${ }^{27}$ Lewis and Farah, "Somalia"; Walls, "Emergence."
} 
stable. ${ }^{28}$ This top-down yet at the same time bottom-up road to peace and reconstruction was characterised by a succession of clan-led national and sub-national reconciliation conferences that provided a forum for reconciliation and which laid the foundations for statebuilding in Somaliland, with the first taking place in Berbera in February $1991 .{ }^{29}$ As shir - ad hoc community councils used as mechanisms of governance within and between clans - these foundational gatherings brought together social and political actors to begin the processes of reconciliation and negotiating the state. ${ }^{30}$ Used as a means through which the Somaliland population could come together through clan and community representatives, these conferences were vital for reconciliation purposes in a war-torn society, and in reaching and relaying a consensus on the future of the territory and its eventual system of government.

The SNM had always advocated that the clan could not be ignored and thus the primary intention of the SNM leadership and subsequent government leaders was to create a state and a government rooted in the clan. A transitional government was appointed by the SNM's council of elders (guurti), who then became members of the new government themselves, institutionalised as the Upper House of Parliament (Golaha Guurtida, or Guurti). Clan elders hold a large amount of influence in Somali society, including as mediators and peacemakers in the resolution of inter and intra-clan conflict and disputes. ${ }^{31}$ Guurti have historically been ad hoc bodies, convened when necessary. Often sitting within shir, guurti are the highest form of political authority within a non-hierarchical clan system. Seen as a key to stability, the continuation of the centrality of elders from SNM to reconciliation and statebuilding government facilitated the environment necessary for the implementation of drastic reform and the creation of the new government.

The structure of the hybrid Somaliland government is a multi-party presidential system with a bicameral legislature and what is meant to be an independent judiciary, although it is widely acknowledged that judicial reform is needed. Somaliland's government was first codified in 1993 with a provisional National Charter, a clan agreement that bound the clans and the state together through customary law. This was replaced by the Somaliland Constitution in 2001. Local officials, the president and the Lower House of Parliament are democratically elected,

\footnotetext{
${ }^{28}$ Bradbury, Becoming, 78-108.

${ }^{29}$ See Renders, Consider; Walls, "Emergence"; Walls and Kibble, "Beyond".

${ }^{30}$ Bradbury, Becoming; Richards, Understanding.

${ }^{31}$ Lewis, Modern.
} 
and the judiciary is appointed. Members of the Upper House of Parliament are selected by clans, with all Somaliland clans and sub-clans represented, although constitutional ambiguity regarding how the membership is determined has posed problems and brought about calls for reform. ${ }^{32}$ Multi-party elections have been deemed free and fair by international observers and peaceful transfers of power have taken place, including transfers between competing political parties in 2005 (Lower House of Parliament) and 2010 (President). The current legal system in Somaliland is a hybrid of codified secular laws, shari' $a$ law and uncodified customary law (xeer) that is comprised of both historic and new inter and intra-clan agreements and settlements. The practice of parallel legal systems reflects, in part, the historical evolution of legal and judicial systems in Somaliland. ${ }^{33}$ The central courts are weak and underdeveloped, and much of the everyday justice and system and reconciliation mechanisms remain with the clans and within the clan system. ${ }^{34}$

Still undergoing consolidation of evolving political settlements, the project and statebuilding process in Somaliland are relatively new and are incomplete. Whilst the government itself is weak, it exists not despite opposition, but largely because of it. Political opposition has been accepted within Somaliland, and negotiating solutions to obstacles or addressing oppositional challenges has become a feature of the forming Somaliland government. Indeed, Somaliland is negotiating a government, and a state, as much as it is building one. ${ }^{35}$

Arguably in Somaliland the state is a political process rather than a governing entity, with the government as the tangible reflection of this. Indeed, the state in Somaliland is a complexity of motivations and ideas embodied by the institutions, symbolic of not only the process but also expectations and desires. Much of what is driving the Somaliland process is a desire for peace and stability, but also to be legally separate from the south. The former is selfexplanatory, but is also seen by many as a condition for the latter. The realisation of independence depends on international recognition of sovereignty, the circular dependence between domestic stability and external recognition underpins many of the political processes

\footnotetext{
${ }^{32}$ See Richards, Understanding.

${ }^{33}$ WSP/APD, "Facilitating."

${ }^{34}$ Moe and Simojoki, "Custom"; WSP/APD, "Facilitating."

35 Terlinden and Renders, "Negotiating."
} 
and actions in Somaliland today, including the maintenance of peace and the style and functions of the government. ${ }^{36}$

Despite its weakness, the stability of the government is seen as vital to survival, or even birth, of the state. It is robust because of its place within the Somaliland project and the flexibility afforded to it by the statebuilding process, but it is also fragile because of its precarious position within a more than 20 -year project that has yet to fulfil the promise of sovereignty. Indeed, it is the possibility, or the impossibility, of the idea of an independent state becoming reality that is the biggest point of fragility for Somaliland. Because of this, for continued stability in the face of fragility it is vital that the domestic sovereignty, as well as the legitimacy underpinning that, do not rest solely with the government.

The dynamism of Somaliland politics and society means that the state is constantly adapting to changing circumstances. Statebuilding has not been unproblematic, with numerous crisis points that could have derailed the process. However, the process has been resilient. There are mechanisms and socio-political factors that have facilitated this within Somaliland. Motivations for recognition, desire for political change, rhetoric, invocations of collective memory and narratives of statehood are amongst the intangible in the complex web of political space in Somaliland. Amongst the tangible, though, one key factor stands out amongst a broad range of political actors: the inclusion of traditional clan mechanisms, both practically and symbolically, in governance and the government. The clan, as a sociopolitical institution that sits both within and above the government, contributes to the strengthening of legitimacy, whilst at the same time also threatening it.

The structure of the state utilises pre-existing and trusted power mechanisms that have assisted with creating the flexibility and adaptability necessary for political change to proceed. Although limited by structural constraints and changing political culture, ${ }^{37}$ clan institutions have provided continuity of governance and of a socio-political link, both of which have been key aspects of stability and equilibrium. This adaptability creates risk and fragility but at the same time also creates a point of resilience. Three primary areas where this can be identified are governance, law and justice, and conflict resolution.

\footnotetext{
${ }^{36}$ Interview, M. Duale.; Richards and Smith, "Playing."

${ }^{37}$ See Höhne, "Limits."
} 


\section{Governance}

Somali pastoralist society was governed through 'ordered anarchy,' not constituted on central institutional rule but also not without governance or rules. ${ }^{38}$ Its egalitarian and openly participatory nature maintained order through what Bradbury identifies as 'collective social institutions and through reciprocal, rule-bound behaviour delineated in customary law'.39 Shir, and within that guurti, were convened when need determined, and it was during these that clan or sub-clan affairs were managed, conflicts were resolved, and the balance between the clans and sub-clans was maintained, providing a 'structure for inter-group relations and governance [and] for organizing and managing violence' ${ }^{40}$ With clan elders being the most respected men and societal peacekeepers, decisions made by the guurti were binding customary law that were passed down through the generations, creating a legal system and governance structure. ${ }^{41}$

The continued existence of these councils and customary law have been instrumental in the post-conflict reconciliation and statebuilding processes, and thus political resilience, in Somaliland. With layers of clan governance and central government existing both separately and in tandem, the clan is an agent of governance and provision, filling the 'governance gap' where the central government is weak and contributing to the governance necessary for peaceful co-existence within society at the sub-state and central levels. ${ }^{42}$ Although undeniably altered through its political institutionalisation, the Somaliland House of Elders is a powerful symbolic reminder of these traditional councils as well as a practical inclusion of clan governance in the central government. The system is not perfect, and not all clans fully support the current form or functions of the government. ${ }^{43}$ Further, some of the biggest threats to Somaliland's stability stem from grievances of some of the clans, particularly those in the eastern provinces. However, the intertwining of clan governance and central democratic government in the overall provision of governance in Somaliland is a striking feature of not only the government but also governance and the political resilience of Somaliland.

\footnotetext{
${ }^{38}$ Lewis, Pastoral.

${ }^{39}$ Bradbury, Becoming, 16.

${ }^{40}$ Ibid., 15.

${ }^{41}$ Bradbury, Becoming; Lewis, Modern.

${ }^{42}$ Bradbury, Becoming; Lewis and Farah, "Somalia".

${ }^{43}$ Bradbury, Becoming; Höhne, "Traditional"; Höhne, "Limits”; ICG, "Somaliland."
} 
As a mechanism of resilience, the inclusion of the clan has facilitated flexibility ${ }^{44}$ and continuity that was necessary to maintain societal investment in the process. During the initial stages of statebuilding the clan served as a tempering link; it helped bridge the gap between the 'old' and 'new' forms of governance and between the government and the population. ${ }^{45}$ In the government, the House of Elders was inextricably linked to both the state and the people through the common denominator of the clan, putting it in a position where it was both part of and outside or above the state, 'hold[ing] together the government, society and culture' ${ }^{46}$ Even though the traditional council of elders has been altered to fit its contemporary institutionalised role, the trusted clan association in the Upper House was significant. Tasked with guidance as well as restraint, the elders became a point of reassurance for a population that had very little, if any, experience of democracy and had very violent experiences with centralised rule. The inclusion of the clan elders was a vital component in a period of drastic change, providing continuity in governance and helping to negotiate Somaliland culture and traditions with democracy and the modern state. The Upper House helped ease tensions in the transitions and transformations taking place in Somaliland, providing a form of safety net that created space for responding to problems, obstacles, crisis and change. Even though in this capacity the role of the clan was largely symbolic, it has been an important component of resilience in Somaliland.

As the statebuilding process continues internal dynamics are changing. The House of Elders is not nor should be immune from this, and increasingly it finds itself at the centre of calls for reform. However, Somaliland's path to the 'state' was self-led and thus responsive to local needs, considerations, and demands. Indeed, an advantage of this self-led path created the flexibility needed to accommodate the socio-political change that is inevitable within statebuilding. The Somaliland state has a significant amount of latitude in the exercise of sovereignty, largely stemming from the presence of the clan elders in the government. Most importantly, their inclusion created a level of central governance that not only resided within the government but also existed despite it, ensuring that during periods of transition or in the event of a political crisis central governance would continue to exist through the traditional

\footnotetext{
${ }^{44}$ Richards and Smith, "Playing."

${ }^{45}$ Interview, A. Hassan.

${ }^{46}$ Ahmed, "Remittances."
} 
institution. In its place both within and above the government, internally rather than externally rooted sovereignty exercised by the traditional authority is extensible, and including this Somali component of governance alongside modern institutions in the central government created a safeguard for the forming state. For Somaliland, the utilisation of traditional authority was the best, and possibly only, option for the stabilisation of a contentious and potentially volatile society during that period of extreme transition and of the initial stages of statebuilding that followed. This inclusion of clan governance, both practically and symbolically, helped facilitate resilience in Somaliland's statebuilding process.

\section{Law and Justice}

In 1993 Somaliland's first constitutional documents were established as customary law (xeer). Historically and traditionally, the Somaliland clan system has provided a system of law and justice through agreements made between clans. Unwritten customary laws (xeer) create the 'lynchpin of orderliness'; handed down orally through the generations, these laws bind members of clans and other socio-political groups to the agreements of the previous generations, forming a repository of law and practice. ${ }^{47}$ As customary law, the legal foundation of the Somaliland state is not only a form of agreement between the clans, but it is also a means through which the clans are bound to the state. This utilisation of the customary within the emerging democratic system is a defining characteristic of Somaliland's hybrid legal and judicial systems.

In addition to clans, Somali society is also divided into diya (blood money) groups. These groups are a means of policing the clans and enforcing the traditional legal system through collective action, creating a 'self-help' justice system that 'provides a sanction against violence and reinforces collective responsibility'. ${ }^{48}$ Together, the clans, diya groups, and xeer form the basis of the traditional Somali legal system, functioning in tandem with the formal legal institutions. ${ }^{49}$ Customary law is an accepted and integral component within the state's legal system, and diya groups supplement the still weak justice system. These groups and

\footnotetext{
${ }^{47}$ Bradbury, Becoming; Drysdale, Stoics.

${ }^{48}$ Bradbury, Becoming, 16; Moe and Simojoki, "Custom."

${ }^{49}$ Menkhaus, "Kenya-Somalia"; Moe and Simojoki, "Custom."
} 
mechanisms help maintain societal stability by helping to ensure that disputes are resolved and extrajudicial retribution is not sought.

Although diya groups and customary law act as important components of the legal and justice system, they also play an important role in maintaining a balanced co-existence within and between the clans; they are 'secular lifejackets which keep Somalis afloat irrespective of codified systems of governance'. ${ }^{50}$ As Lewis notes, as the Somali clan system is inherently unstable, and because the strong bond of kinship and therefore identity can both unify and divide society, the contracts and agreements made between and within the clans 'cement[s] and temporarily stabilize[s] fission and fusion in the lineage system'. ${ }^{51}$ Customary law consists of explicitly formulated obligations, rights and duties, defining basic values and rules of behaviour and binding people together in internal and external matters. It is a close equivalent to the notion of a social contract. Knowledge of and abidance by these customs and laws creates an overarching form of legal governance; the agreements and treaties that become customs and laws form stable grounding between the clans, and as society encounters new situations and conditions the contracts and customs are revised accordingly. The evolution of a 'common xeer', built up over centuries of interaction, cooperation and competition, and the retention of such values helped in resolving conflicts during the lead-up to and following the 1991 collapse of Somalia, and later in establishing peace and a government in Somaliland. ${ }^{52}$

The role of the clans in law and justice goes beyond this, though. In Somaliland, judicial reform is an ongoing political issue. The 'modern' Western-style legal system and codified laws are underdeveloped and plagued with inefficiency, and judicial independence is an acute concern. Alone, the 'modern' component of the judicial system is an obstacle to continued democratic development. ${ }^{53}$ However, Somaliland's legal system is a hybrid one, bringing together 'Western' institutions with shari'a law and xeer. Where the 'modern' is weak or still developing, institutions such as xeer and diya groups fill the gaps and serve as a mechanism for law and justice. In many ways, forms of legal order are embedded within social structures; structures that sit outside the state yet co-existing and reside within the institutions

\footnotetext{
${ }^{50}$ Drysdale, Stoics, 141.

${ }^{51}$ Lewis, "Clanship," 281.

52 Bradbury, "Peace-Enforcement."

${ }^{53}$ Bradbury, Becoming; WSP/APD, "Facilitating."
} 
of the state. This socially based legal system forms the bedrock of the 'day-to-day' justice system in Somaliland.

Somaliland's legal and judicial development and reform have been slow and both the traditional and the modern institutions pose problems for the state. The 'modern' institutions are weak and, as noted above, lack of judicial independence is a concern. Structural advantages of the clan system, specifically related to clan position and strength, creates uneven access to justice. ${ }^{54}$ Contradictions and contestation between the two legal systems creates the possibility of what Höhne calls a 'crippled hybridity, ${ }^{55}$ However, statebuilding is a process, and in that is the expectation for development and change. In this, the utilisation of traditional institutions was a key mechanism for the maintenance of law and justice in the absence of 'modern' institutions, and arguably facilitated the creation and ongoing development of those modern institutions. Customary law underpins the legal foundations of the government and the statebuilding process and as such binds state and society, and the traditional institutions have allowed for a continuation and balance in the face of a weak or absent state. Further, traditional law and justice practices and institutions work as a mechanism of conflict prevention and resolution within society. Thus, as a mechanism of resilience, clan practices and institutions work to maintain equilibrium, as well as to facilitate adaptation and balance.

\section{Conflict Resolution}

In Somali society, co-existence between the clans is a necessary component of peace and stability, and Somali society works on a system of 'balanced opposition between groups...If peace is thought to exist where there is an equitable balance, anything which upsets the balance will continue conflict'. ${ }^{56}$ This need for balance means conflict resolution mechanisms have become embedded in the clan structure itself; mechanisms such as diya groups for lesser, more personal crimes, and clan councils in the instance of inter or intra-clan conflict. In some instances smaller conflicts can be resolved through marriage agreements, serving to tie two feuding clans or sub-clans through custom. ${ }^{57}$ Within these mechanisms, clan elders, often within guurti, hold primary responsibility for resolving conflicts. For the elders,

\footnotetext{
${ }^{54}$ See Schlee, 'Customary law'.

${ }^{55}$ Höhne,'One Country', 186.

${ }^{56}$ Bradbury, "Peace-Enforcement," 6.

${ }^{57}$ Drysdale, Stoics.
} 
negotiation and compromise are essential tools and are commonplace in restoring balance and resolving conflict. Through the often lengthy, loud and dynamic negotiation process, grievances are brought to the attention of all involved and the 'air is cleared' ${ }^{58} \mathrm{In}$ Somaliland, this subs-state conflict resolution practice creates a foundational mechanism of resilience within a political entity that needs to maintain peace whilst undergoing the turbulence of statebuilding.

Resolutions to conflicts are typically negotiated by the most respected elders, with the agreements becoming xeer. As such, customary law becomes the first route for settling disputes and hostilities. ${ }^{59}$ Elders in Somaliland today list other tools used in their peacemaking role: age, shari'a law; proverbs and poems; shir; devotion to the public interest; impartiality; using clan resources as an indication of commitment to process; compromise and consensus; and persistence. Significantly, the elders also list 'transparency, fairness, trust and sincerity' as 'tools for the mutual trust and confidence building' ${ }^{60}$ Trust and respect for the elders provides the basis for their abilities; without these their actions would be meaningless. Because of the intricacies and lasting nature of xeer, clan elders are responsible for ensuring that conflicts are resolved as future violations would be subject to diya compensation. As such, in places where the clan system remains central to law and governance, elders, through conflict resolution mechanisms, provide a point of resilience, acting to constantly negotiate balance and co-existence within society. ${ }^{61}$

This exists on both the local and the national levels. Local mechanisms are more visible and tangible acts of resolution that have a more practical every day impact on society. In more severe cases of conflict or potential conflict, local actions often also individual members of the Upper House of Parliament who represent both the government and the clan and who are constitutionally tasked with addressing and resolving conflict in the territory. ${ }^{62}$ Although at the national level this responsibility is much more symbolic than hands on, the presence of conflict resolution mechanisms that reside within the traditional body help ensure a systemic continuity of peace, and in the event of crisis, provide a means through which equilibrium

\footnotetext{
${ }^{58}$ WSP/APD, "Plunder" 63.

${ }^{59}$ Lewis, Modern.

${ }^{60}$ Guurti, "Somaliland"

${ }^{61}$ Drysdale, Stoics, 13.

${ }^{62}$ Walls, "Emergence."
} 
can once again be found. In that, both levels serve to provide mechanisms of resilience that together work to maintain peaceful foundations for the statebuilding process.

Clan conflict resolution mechanisms as points of resilience extend beyond the work of elders. The end of the 1994-6 Somaliland civil war, a conflict that arose due to tensions from political transition, disputes over power-sharing, control over resources, and divisions within the political elite were negotiated largely by professionals from the diaspora using traditional mechanisms of conflict resolution. ${ }^{63}$ The war formally ended following a national reconciliation conference, the Hargeisa Conference, which was reminiscent of the early statebuilding shir. Although in this instance conflict resolution was not initiated by the clans, the utilisation of traditional structures and resolution mechanisms does indicate the importance of these clan provisions.

Somaliland has faced intra-governmental crises, but historically these have been obstacles rather than ultimately destabilising events. Amongst its constitutional powers, the House of Elders advises the lower house of parliament on shortcomings in the administration of government, and holds the mediation capacity of a council of elders. These responsibilities have been broadly interpreted by the government and the body itself during the statebuilding process, with considerable latitude conceded. These interpretations have resulted in the House's intended role as the mediating influence in Somaliland politics and the state formation process. Although this carries problematic implications of its own and the future of this role is uncertain, ${ }^{64}$ on numerous occasions the Upper House has both overtly and subtly exercised its responsibility to reconcile between branches of government. It has often provided fora in which problems can be addressed and resolved, as well as in some instances acting as the referee. In this capacity, the House of Elders acts in a quasi-judicial manner that is similar to the historic role of the ad hoc guurti. The body's overall role in the statebuilding process has changed since 1991, and there are complications associated with the House being a political actor entrenched in the institution in which it is mediating. However, the continued stabilising influence of the elders has thus far outweighed complications. The combination of both local and national clan efforts has been instrumental in addressing most physical and political conflict as, and often before, it occurs.

\footnotetext{
${ }^{63}$ Bradbury, Becoming, 116; see also Renders, Consider.

${ }^{64}$ See Höhne, "Limits"; Terlinden and Renders, "Negotiating."
} 


\section{SOMALILAND AND POLITICAL RESILIENCE}

Because of and through these three key areas, the Somaliland clan has been vital to political resilience within the Somaliland state and the statebuilding process. The impacts of this extend beyond these areas, though, as when the state was weak, absent or violent the clan has historically and continues to fill the gaps of provision typically managed by the state. ${ }^{65}$ In this way, these resilience mechanisms are not limited to the institutions of the state, but also act to underpin an almost circular relationship between the state and the population in areas that are vitally important to maintain socio-political stability and thus the continuation of statebuilding.

Undeniably the institutionalised clan body - the House of Elders - is far from the traditional guurti, and it is widely acknowledged within Somaliland that the members of the House have long been politicised. It is also suspected that the guurti's inclusion as a government institution was not as much to achieve an idealised vision of Somali government but rather was payment for the elders' work during the war and the immediate post-conflict period. ${ }^{66}$ Still, by institutionalising the clan within central government, it becomes not only a practical but also a symbolic inclusion that transcends many political accusations and suspicions and serves a purpose in its own right. Practically, the Upper House is charged with 'traditional' tasks such as ensuring religious and customary law are upheld and maintaining peace and security in the territory. The House is also responsible for mediating and resolving conflict within the government. Symbolically, the clan has significant mediation roles, particularly in mediating co-existence between the two forms of governance in the territory. Although not always a tangible act of mediation, the inclusion of the clan in the central government acts as point of reassurance and also as a governance safety net, both for the government and for the population. Through the Upper House, the clan and clan governance exist both within and above the government, ensuring not only a continuation, or at least invocation, of the recognised importance of the clan, but also offering assurances that governance exists despite the government. The clan is a central part of both the government and the state. The clan is

\footnotetext{
${ }^{65}$ Interview, M. Hassan.

${ }^{66}$ Höhne, "Limits"; Renders, Consider; Terlinden and Renders, "Negotiating."
} 
invested in the state, and because of the nature of the Somaliland statebuilding project, the state is rooted and invested in the clan; the two are inextricably entwined. ${ }^{67}$

As a mechanism of resilience, the clan has been central to 'holding together' the project in Somaliland. The state, as an unrecognised entity and undertaking self-led and self-styled statebuilding, depends upon continued support and legitimacy from the population, and the population depends on the state for fulfilling promises of peace and sovereignty. Because of the precarious nature of the project, the clan acts as a facilitator and a buffer, mediating, negotiating and resolving potential conflicts or conflicting actors, ideas, expectations and processes, as well as filling gaps where the state and the government are weak. Symbolically, this mechanism acts to provide balance, mediation and reassurance within a rapidly evolving socio-political space. In the early stages of statebuilding in Somaliland, the clan and the Upper House earned the nickname of the 'spine' of Somaliland. Clan mechanisms have facilitated facilitates flexibility and adaptability, as well as providing a point of equilibrium and a means to return to it.

\section{CONCLUSIONS}

It would be inaccurate to claim that the centrality and use of the clan is the only mechanism that has contributed to the continuation of statebuilding in Somaliland. The work and existence of a multitude of actors, structures and processes have been vital. ${ }^{68}$ Indeed, the state in Somaliland and the processes surrounding its creation and continuation are centred on complex and evolving relationships between political processes and society. The success of this is underpinned by the fostering of these relationships and the rooting of the state in society and society in the state. A point of resilience, therefore, is the continuation of the state along the agreed upon lines that have emerged and evolved. In the statebuilding process, the clan, as a common denominator between the state and society, has been instrumental in establishing and maintaining this. However, there is an inherent fragility within Somaliland's success; fragility found not only within the precariousness of the state in the condition of non-recognition, but also in the mechanisms central to maintaining the continuation of the process.

\footnotetext{
${ }^{67}$ Richards, Understanding.

${ }^{68}$ WSP/APD, "Plunder"; Abokor et al., "Further"; Lindley, "Somalia."
} 
In Somaliland today, the resilience mechanism of the clan is becoming a pressure point for the state's latent fragility. Much of the influence of the clan is its power in the symbolic rather than the practical; the clan has acted as the trusted 'known' in an unfamiliar and turbulent process of socio-political change. As the state changes, though, so does the power of the clan. The placement and role of the clan was never set in stone. Indeed, constitutional ambiguity regarding the composition and role of the House of Elders indicates flexibility for change as socio-political relationships evolve. As the modern state and democracy become more familiar in Somaliland, relationships and expectations are changing, including those surrounding the role of the clan. Increasingly the clan's presence within the government is recognised as being overly political and thus incapable of fulfilling the original intent. Accusations of corruption and co-option by a powerful executive date back to 1991, but the self-extension crisis of $2006^{69}$ sparked serious concerns about and objection to an unchecked powerful body within a modernising government. ${ }^{70}$ What had been instrumental in balancing the demands of governance in the statebuilding process thus poses a threat to the continuation of the process. As the process of statebuilding continues the role and placement of the clan both symbolically and practically - must be addressed and resolved in order to prevent the institution from unbalancing a system it is tasked with maintaining equilibrium in.

As an unrecognised state, Somaliland has much invested in the maintenance of peace and of a stable political apparatus. The quest for statehood is a strong unifying factor within Somaliland and the anticipation of recognition facilitates political change and local ownership in that change. Importantly, it also promotes resilience. However, because of this there is also very little room in Somaliland for error. The resilience of the state, and thus the dream of sovereignty, rests upon the not only the maintenance of peace and the continuation of the political process, but also upon the maintenance of societal support for the project. Engaging not only the Somaliland people but also the familiar and effective clan structures in these processes helped to create a system of resilience suited to Somaliland's particular social and political needs during the period of statebuilding. The inherent fragility of Somaliland depends upon these structures to uphold and continue the process not only between society and the state, but also within the government itself.

\footnotetext{
${ }^{69}$ See Richards, Understanding, Ch. 7.

${ }^{70}$ Höhne, "Limits"; Terlinden and Renders, "Negotiating."
} 
As the case of Somaliland demonstrates, using the language of resilience to analyse the role of socio-political actors and processes that sit within but also outside of formal state structures is beneficial in identifying mechanisms that exist within statebuilding but are not always recognised. It also highlights the web of intertwined nature of stability and fragility, and forces consideration of a symbiotic relationship rather than a spectrum. Of course it would be methodologically problematic to draw conclusions from one case to apply to a generalised context. However, it remains important to consider individual cases to question, or even inform, broader understandings. When considering statebuilding, we often ask questions about stability and fragility, but we rarely ask questions about them together. When considering statebuilding we must also ask questions about what could make a state sustainably stable, and about how those actors and processes can be recognised and understood within the process of statebuilding. These questions naturally guide understandings of the process of statebuilding away from a pre-determined end and towards an approach that better allows for the flexibility required for statebuilding; it better allows for a consideration of individual factors, histories and circumstances that cannot be divorced from any form of political change. The conceptual lexicon of resilience incorporates the language of flexibility, and bringing that into analysis of politics and specifically of statebuilding, facilitates a more comprehensive assessment and a more nuanced understanding. 


\section{REFERENCES}

Abokor, A.S., S. Kibble, H. Yusuf, and G. Barrett. "Further Steps to Democracy: The Somaliland Parliamentary Elections, September 2005." London: Progressio, 2006.

Ahmed, I. "Remittances and Their Economic Impact in Post-War Somaliland." Disasters 24, no. 4 (2000): 380-89.

APD. A Self-Portrait of Somaliland. Hargeisa/Nairobi: WSP International, 2005.

Boege, V., M.A. Brown, and K. P. Clements. "Hybrid Political Orders, Not Fragile States." Peace Review 21, no. 1 (2009): 13-21.

Bradbury, M. Becoming Somaliland. Oxford: James Currey, 2008.

. "Peace-Enforcement, Peace-Making and Peace-Building: Options for Resolving the Somali Conflict." London: Oxfam, 1993.

Chandler, D. "International Statebuilding and the Ideology of Resilience." Politics 33, no. 4 (2013): 276-86.

Drysdale, J. Stoics Without Pillows. London: HAAN Associates, 2000.

Duale, A. Somaliland Minister of Foreign Affairs, Hargeisa, 2006.

Duffield, M. "Challenging Environments: Danger, Resilience and the Aid Industry." Security Dialogue 43, no. 5 (2012): 475-92.

Finnemore, M. National Interests in International Society. London: Cornell University Press, 1996.

Guurti. "Somaliland: A Model, Indigenous Owned Peace and Democratic Governance Building in the Horn of Africa." Hargiesa, 2006.

Hassan, A. Chairman of Guurti Human Rights and Social Affairs Sub-Committee, Hargiesa, 2006.

Hassan, M. Lead Researcher, Somaliland Academy for Peace and Development, Hargeisa, 2006.

Höhne, M. "One country, two systems: Hybrid political orders and legal and political friction in Somaliland." O. Zenker and M. Höhne (eds), The State and the Paradox of Customary Law in Africa. London: Routledge (2018): 184-212.

"Limits of Hybrid Political Orders: The Case of Somaliland." Journal of Eastern African Studies 7, no. 2 (2013): 199-217.

."Traditional Authorities in Northern Somalia: Transformation of Positions and Power." Working Paper. Max Planck Institute for Social Anthropology, 2006.

ICG. "Somaliland: Democratisation and Its Discontents." Africa Report. Nairobi/Brussels: International Crisis Group, 2003.

Joseph, J. "Resilience as Embedded Neoliberalism: A Governmentality Approach." Resilience 1, no. 1 (2013): 38-52.

Klein, R, R. Nicholls, and F. Thomalla. "Resilience to Natural Hazards: How Useful Is This Concept?" Global Environmental Change Part B, no. 1 (2003): 35-45.

Lemay-Hebert, N. "Statebuilding without Nation-Building? Legitimacy, State Failure and the Limits of the Institutionalist Approach." Journal of Intervention and Statebuilding 3, no. 1 (2009): $21-45$.

Lewis, I.M. A Modern History of the Somali. Oxford: James Currey, 2002.

. A Pastoral Democracy. Oxford: Oxford University Press, 1961.

“Clanship and Contract in Northern Somalia." Africa 29 (1959): 274-93. 
Lewis, I.M., and A. Farah. "Somalia The Roots of Reconciliation" London: Action Aid, 1993.

Lindley, A. "Somalia Country Study." Oxford: DFID, EC, Deloitte and Touche, 2005.

MacGinty, R. "Indigenous Peace-Makers Versus the Liberal Peace." Cooperation and Conflict 43, no. 2 (2008): 139-63.

Manyena, S.B. and S. Gordon. "Bridging the Concepts of Resilience, Fragility and Stabilisation." Disaster Prevention and Management 24, no. 1 (2014): 38-52.

Menkhaus, K. “Kenya-Somalia Border Conflict Analysis.” Washington DC: USAID, 2005.

Moe, L.W., and M.V Simojoki. "Custom, Contestation and Co-Operation: Peace and Justice Promotion in Somaliland." Journal of Conflict, Security and Development 13, no. 4 (2013): 393-416.

Prior, T. and J. Hagmann. "Measuring Resilience: Methodology and Political Challenges of a Trend Security Concept." Journal of Risk Research 17, no. 3 (2014): 281-98.

Renders, M. Consider Somaliland. Leiden: Brill, 2012.

Richards, R. Understanding Statebuilding: Traditional Governance and the Modern State in Somaliland. London: Routledge, 2014.

Richards, R. and R. Smith. "Playing in the Sandbox: State Building in the Space of NonRecognition." Third World Quarterly 36, no. 9 (2015): 1717-35.

Richmond, O. "Decolonising Security and Peace." In Conflict Resolution and Ontological Security, 172-92. London: Routledge, 2015.

- Peace Formation and Political Order in Conflict Affected Societies. Oxford: Oxford University Press, 2016.

—. 'Failed by Design? The Collapse of Statebuilding'. Millennium, forthcoming.

Roberts, D. "Hybrid Polities and Indigenous Pluralities." Journal of Intervention and Statebuilding 2, no. 1 (2008): 63-86.

Schlee, G. "Customary Law and the joys of statelessness." Journal of Eastern African Studies 7, no. 2 (2013): 258-271.

Sisk, T. Statebuilding. Cambridge: Polity, 2013.

Terlinden, U. and M. Renders. "Negotiating Statehood in a Hybrid Political Order: The Case of Somaliland." Development and Change 41, no. 4 (2011): 723-46.

Walls, M. "The Emergence of a Somali State: Building Peace from Civil War in Somaliland." African Affairs 108, no. 432 (2009): 371-89.

Walls, M. and S. Kibble. "Beyond Polarity: Negotiating a Hybrid State in Somaliland." Africa Spectrum 45, no. 1 (2010): 31-56.

WSP/APD. "From Plunder to Prosperity: Resolving Resource-Based Conflict in Somaliland." Hargeisa/Nairobi, 2006.

Zebrowski, C. "The Nature of Resilience.” Resilience 1, no. 3 (2013): 159-73. 